\title{
Breast cancer: equal rights?
}

Ana Fátima Carvalho Fernandes ${ }^{1}$

There is not any statistics related to encouraging breast cancer along the past century, and there has not been any in present century. It has been published in the scientific and lay press information on the crescent number of women attacked by breast cancer. How to spare women and family members of such pain when they experience this disease? Which rights provide assistance to the women with cancer?

The public policies related to breast cancer developed in Brazil have been promulgated since the years 1980s and, updated during this whole period. The objectives of the actions for the control of breast cancer aims at reducing the exposition to risk factors, decrease the mortality, and improve the quality of life of the woman, among others.

It consists of a strategy of early diagnosis: to alert the population for the signs and suspect symptoms of cancer; health professionals trained for the evaluations the suspect cases and systems and health services prepared to guarantee the opportune diagnosis confirmation. So, the rights to prevention and to an early diagnosis are primordial conditions in order to have an early knowledge of the possibilities of risk, and in the case the patient is sick, avoid the advance of the disease and reduce surgical processes.

The woman with cancer, besides being in the pursuit of her survival, experiences her being away of her everyday life, aggressive treatment, affected self-image, and medicine used uninterruptedly throughout her life, besides the need of frequent returns to the health services, impediment to develop some functions among other roles.

Under the Brazilian law, the person with cancer has the legal support assured by the law, which grants rights and benefits to those patients and their family members. The Federal Brazilian Constitution assures the patients with neoplasia special rights, however there is not enough information and many do not take advantage of such benefits for the lack of knowledge of those rights ${ }^{(1)}$.

The rights of the patient are granted by several documents, among them the Letter of the Rights of the Users of Health, once the diagnosis is proved through a medical register or through the expertise of the Instituto de Previdência Social (Social Security Institute). As it is assured, the laws are indistinctly equal for all, without prejudice or prioritization; however there is a distance between the written law and the health services.

The diagnosis of cancer transforms the patients and their family members physically and psychologically, in their psychological, physical and financial scope. In case there is no assistance to their rights, it becomes a legal action when the patients searches for health through the Unified Health System or through a private health plan, where there is a need to use social security, funds for time worked, exemption of taxes, working rights, consumer rights, funds from private insurance plans, total payment of mortgage, priority in justice, free transportation, free recovery surgery, home palliative care, free medicine of continuous use, among other rights of the Law, but, in order to make them effective and guarantee them of their rights, many times it is necessary to go to Judicial Custody ${ }^{(1)}$.

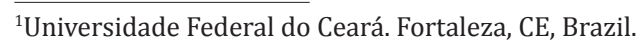

Corresponding author: Ana Fátima Carvalho Fernandes

Rua Alexandre Baraúna, 115 - Rodolfo Teófilo. CEP: 60430-160. Fortaleza, CE, Brazil. E-mail: afcana@ufc.br 
During the experience of a serious disease, the level of equality among citizens represents a new picture, once the patients, besides searching for the maintenance of their life, has to face other issues, such as being away of their daily lives, the treatment many times is more aggressive, there is the need of other medicine which increase the family budgets and a differentiated eating habits, so the patient has a new role in the family scope, the dependence on other people and even on the system of psychological therapy in order to cope with the disease. Many times, one of these facts lead the woman to disparate situations: the quitting of the treatment or the search of groups or entities of support.

The women with breast cancer suffer with the disease and many times do not know their rights while being a breast cancer bearer, and then they do not use them to guarantee at least an encouragement in this so difficult moment of their lives ${ }^{(2)}$.

According to the above mentioned, the health professionals urge to assist women in the access to the health services at all level of assistance, and, especially in the prevention of cancer; interact, communicate their legal rights, allowing them to have the guarantees of the right of citizenship and of all the benefits conferred facing a malign neoplasia.

\section{References}

1. Rosa LFA, Girardon-Perlini NMO, Couto MS, Cardos AL, Birk NM. Direitos legais da pessoa com câncer: conhecimentos de usuários de um serviço de oncologia público. Rev Enferm UFSM. 2014; 4(4):771-83.

2. Lopes CV. A mulher paciente de câncer e seus direitos. [Internet] 2014 [citado 2014 dez 12]. Disponível em: http://www.femama.org.br/novo/arquivos/0.035934001278455875.pdf 